\title{
Kesan Resonans Plasmon Aurum terhadap Prestasi Fotoelektrokimia Fotokatod $\mathrm{Cu}_{2} \mathrm{O}$
}

(Plasmonic Resonance Effect of Aurum on Photoelectrochemical Performance of $\mathrm{Cu}_{2} \mathrm{O}$ Photocathode)

\author{
KIM HANG NG, LORNA JEFFERY MINGGU*, NURUL AKMAL JAAFAR \& MOHAMMAD B. KASSIM
}

\begin{abstract}
ABSTRAK
Dalam kajian ini, kesan lapisan Au di atas fotokatod kuprus oksida $\left(\mathrm{Cu}_{2} \mathrm{O}\right)$ terhadap tindak balas fotoelektrokimia telah diuji. Lapisan $\mathrm{Cu}_{2} \mathrm{O}$ dan Au ini telah disediakan di atas subtrak kaca stanum oksida terdop fluorin (FTO) dalam konfigurasi yang berlainan, melalui kaedah elektroendapan. Selepas itu, fotokatod ini dicirikan dengan mikroskopi elektron imbasan berpancaran medan (FESEM), spektroskopi ultra lembayung dan cahaya nampak (UV-Vis) dan analisis fotoelektrokimia. Daripada imej FESEM, lapisan Au telah berjaya diendapkan di atas substrak FTO dan permukaan $\mathrm{Cu}_{2} \mathrm{O}$. Penyerapan plasmon Au pada julat cahaya nampak juga terbukti dan ia telah mempertingkatkan penggunaan cahaya nampak untuk tindak balas fotoelektrokimia. Oleh itu, prestasi fotoelektrokimia fotokatod $\mathrm{Cu}_{2} \mathrm{O}$ berplasmon telah meningkat secara ketara. Di bawah sinaran suria simulasi A.M 1.5, fotokatod $\mathrm{Cu}_{2} \mathrm{O}$ terapit Au telah menjanakan ketumpatan fotoarus yang terting gi, iaitu 4 kali ganda peningkatan berbanding prestasi fotokatod $\mathrm{Cu}_{2} \mathrm{O}$ tulen .
\end{abstract}

Kata kunci: Fotoelektrokimia; logam oksida; plasmon

ABSTRACT

In this work, the effect of Au layer on cuprous oxide $\left(\mathrm{Cu}_{2} \mathrm{O}\right)$ photocathode on photoelectrochemical reaction was studied. The $\mathrm{Cu}_{2} \mathrm{O}$ and Au layer were prepared on a fluorine-doped tin oxide (FTO) glass substrate in different configurations, via electrodeposition method. Then, the photocathodes were characterized by field-emission scanning electron microscopy (FESEM), UV-Vis spectroscopy and photoelectrochemical analysis. From the FESEM images, the Au layer was sUccessfully deposited onto the FTO substrate and the surface of $\mathrm{Cu}_{2} \mathrm{O}$. The plasmonic absorption of Au at visible light region was proven and it improved the utilization of visible light for photoelectrochemical reaction. As a result, the photoelectrochemical performance of the plasmonized $\mathrm{Cu}_{2} \mathrm{O}$ photocathode improved significantly. Under simulated AM 1.5 solar illumination, the $\mathrm{Au}$ sandwiched $\mathrm{Cu}_{2} \mathrm{O}$ photocathode generated the highest photocurrent density, which is 4 folds enhancement compared to that obtained by bare $\mathrm{Cu}_{2} \mathrm{O}$ photocathode.

Keywords: Metal oxide; photoelectrochemical; plasmonic

\section{PENGENALAN}

Krisis tenaga merupakan satu isu yang paling mustahak dalam masyarakat kini. Pembangunan ekonomi dan sosial amat bergantung kepada tenaga fosil yang terhad jumlahnya. Senario ini bertambah genting apabila populasi global dan taraf hidup manusia semakin bertambah. Keperluan tenaga yang semakin bertambah dengan sumber tenaga yang semakin berkurang mengakibatkan isu krisis tenaga. Oleh itu, pembangunan tenaga keterbaharuan telah diberi perhatian untuk mengganti tenaga fosil bagi menangani isu krisis tenaga tersebut. Banyak usaha telah ditumpukan dalam penyelidikan tenaga suria, terutamanya sel suria dan kemajuan yang besar telah dicapai dalam beberapa tahun ini (Grätzel 2017; Lewis 2016; Pazos-Outón et al. 2017). Walau pun demikian, teknologi ini menghadapi masalah kerana ketidaktentuan keamatan dan ketiadaan cahaya suria pada waktu malam (Tang 2017). Untuk memastikan bekalan tenaga daripada sumber suria adalah berterusan dan stabil pada siang dan malam, ia memerlukan kaedah penyimpanan tenaga yang berkesan dan murah. Salah satu cara yang menarik adalah dengan menukarkan tenaga suria kepada tenaga kimia (sebagai bahan api), seperti karbohidrat dan hidrogen. Mengambil inspirasi daripada proses fotosintesis dalam tumbuh-tumbuhan yang menukarkan tenaga suria kepada karbohidrat, para penyelidik telah mencadangkan penghasilan hidrogen suria daripada pembelahan molekul air dengan bantuan fotomangkin.

Penguraian molekul air boleh dilakukan melalui teknologi fotoelektrokimia atau fotopemangkinan. Dalam kedua-dua proses ini, tenaga suria akan diserap dan molekul air akan dibelah kepada gas hidrogen dan gas oksigen. Walau pun demikian, dalam sistem fotoelektrokimia, prestasi fotomangkin dapat dipertingkatkan dengan pembekalan keupayaan pincang. Selain itu, gas hidrogen dan oksigen yang terhasil pada katod dan anod yang terpisah juga memudahkan pengumpulan gas hidrogen kerana gas yang terhasil ini tidak tercampur. Oleh itu, kaedah ini tidak memerlukan proses pemisahan dan penulenan gas hidrogen yang melibatkan kos. Ini 
membolehkan sistem fotoelektrokimia menjadi satu pendekatan yang ideal dalam penghasilan gas hidrogen. Tetapi, teknologi ini masih mengalami masalah terutama dalam aspek keberkesanan (Gao et al. 2017; Ng et al. 2018). Fotomangkin yang difabrikasi masih tidak dapat memenuhi syarat untuk pengkomersialan. Pelbagai pengubahsuaian terhadap fotomangkin telah dilakukan, seperti pembentukan struktur nano (Baxter et al. 2014), pengedopan ion (Kalamaras et al. 2016; Ng et al. 2012), penghasilan fotoelektrod berlapisan (Choudhary et al. 2012), pemekaan foto dengan kompleks tak organik (Jaafar et al. 2017; Mark-Lee et al. 2012) dan penglibatan kesan resonans plasmon (Leong et al. 2015; Sim et al. 2014; Ye et al. 2016).

Pengubahsuaian fotoelektrod dengan kesan resonans plasmon merupakan satu pendekatan yang amat menarik untuk mencapai prestasi yang baik dalam tindak balas fotoelektrokimia. Dengan penambahan butiran logam adi yang sedikit, fotoaktiviti fotoelektrod dapat dipertingkatkan berkali ganda. Contohnya, tindak balas fotoelektrokimia yang ditunjukkan oleh $\mathrm{TiO}_{2} / \mathrm{Au}$ yang dihasilkan di atas zink oksida terdop aluminium (Mi et al.2016) telah meningkat sebanyak lima kali ganda dengan penambahan logam adi. Fotoelektrod $\mathrm{Au} / \mathrm{Cu}_{2} \mathrm{O}$ yang dilaporkan oleh (Wang et al. 2017) juga menunjukkan peningkatan fotoarus sebanyak 7.5 kali ganda berbanding $\mathrm{Cu}_{2} \mathrm{O}$ tulen. Selain itu, fabrikasi fotomangkin $\mathrm{Ag} / \mathrm{Cu}_{2} \mathrm{O}$ juga banyak dilaporkan dalam kajian lepas untuk meningkatkan prestasi fotomangkin $\mathrm{Cu}_{2} \mathrm{O}$ dalam penguraian bahan organik ( $\mathrm{Li}$ et al. 2013; Yang et al.2014). Dalam kajian ini, lapisan Au diendapkan dengan konfigurasi yang berlainan untuk meningkatkan prestasi fotoelektrokimia fotokatod $\mathrm{Cu}_{2} \mathrm{O}$.

Julat penyerapan cahaya nampak untuk kesan resonans plasmon amat bergantung kepada saiz butiran logam adi (Hu et al. 2006). Dalam kajian ini, lapisan Au diendapkan ke atas substrat kaca FTO dan $\mathrm{Cu}_{2} \mathrm{O}$ dengan tempoh elektroendapan yang berbeza. Lapisan $\mathrm{Au}$ di atas kaca FTO diendapkan dengan tempoh elektroendapan yang lebih lama (30 min) untuk mendapat butiran Au yang lebih besar untuk menyerap julat panjang gelombang yang lebih panjang. Sementara itu, lapisan $\mathrm{Au}$ di atas permukaan $\mathrm{Cu}_{2} \mathrm{O}$ diendapkan dengan tempoh elektroendapan yang pendek (1 saat) untuk menghasilkan butiran kecil yang menyerap julat panjang gelombang yang pendek. Dengan itu, penyerapan cahaya nampak dapat dipertingkatkan untuk tindak balas fotoelektrokimia.

\section{BAHAN DAN KAEDAH}

Kuprum sulfat pentahidrat, $\mathrm{CuSO}_{4} .5 \mathrm{H}_{2} \mathrm{O}$ (SigmaAldrich), asid laktik (Sigma-Aldrich), natrium hidroksida (Sigma-Aldrich) dan larutan aurum(III) klorida, $\mathrm{HAuCl}_{4}$ (Sigma-Aldrich) digunakan sebagai bahan pemula untuk penyediaan lapisan $\mathrm{Cu}_{2} \mathrm{O}$ dan $\mathrm{Au}$. Substrak kaca FTO telah dicuci dengan etanol, aseton dan air suling di dalam alat ultrabunyi selama $5 \mathrm{~min}$. Butiran Au telah disintesis di atas substrak FTO melalui kaedah elektroendapan, dalam larutan $0.5 \mathrm{mM} \mathrm{HAuCl}$ dan dibekalkan keupayaan sebanyak -0.245 V (lwn. elektrod kalomel tepu) selama $30 \mathrm{~min}$. Langkah ini dilakukan dengan potentiostat (Princeton Versastat 4). Selepas itu, sampel dikeringkan di dalam relau pada suhu $40^{\circ} \mathrm{C}$ selama 10 min. Lapisan $\mathrm{Cu}_{2} \mathrm{O}$ juga disediakan melalui kaedah yang sama. Ia disediakan pada -0.445 V (lwn. elektrod kalomel tepu) di dalam larutan 0.4 $\mathrm{M} \mathrm{CuSO}_{4}$ dan 3.0 M asid laktik. Larutan ini ditambahkan dengan 4.0 M NaOH supaya $\mathrm{pH}$ larutan dinaikkan kepada pH11 bagi mendapatkan $\mathrm{Cu}_{2} \mathrm{O}$ jenis-p yang dikehendaki. Selepas itu, satu lapisan Au diendapkan ke atas permukaan $\mathrm{Cu}_{2} \mathrm{O}$ (Rajah 1). Ini dilakukan dengan kaedah yang sama seperti dinyatakan sebelum ini, tetapi dengan tempoh elektroendapan yang lebih singkat (1 saat). Kaedah ini telah dilaporkan dalam kajian lepas (Ng et al. 2017; Verma et al. 2013).

Seterusnya, sampel dicirikan dengan FESEM (Zeiss Supra 55VP) yang dilengkapi EDX, spektrofotometer UV-Vis (PerkinElmer Lambda 35) dan penganalisis fotoelektrokimia (Princeton Versastat 4) dilengkapi lampu xenon. Penyerapan cahaya oleh filem nipis boleh dikira berdasarkan (1) (Redecka et al. 2008):

$$
\mathrm{T}=\mathrm{e}^{-\mathrm{dd}}
$$

dengan $\alpha$ ialah pekali penyerapan; T ialah normalized transmittance; dan d ialah ketebalan filem (cm). Pekali penyerapan adalah berkaitan dengan jurang tenaga berdasarkan (2) (Hutchins et al. 2006):

$$
\alpha h v=B\left(h v-E_{g}\right)^{n}
$$

dengan B ialah pemalar; $E_{g}$ ialah jurang tenaga; dan $n$ ialah eksponen. Nilai n dianggap sebagai 2 untuk jurang tenaga tidak terus manakala nilai $\mathrm{n}$ dianggap sebagai 0.5 untuk jurang tenaga terus. Pengiraan jurang tenaga

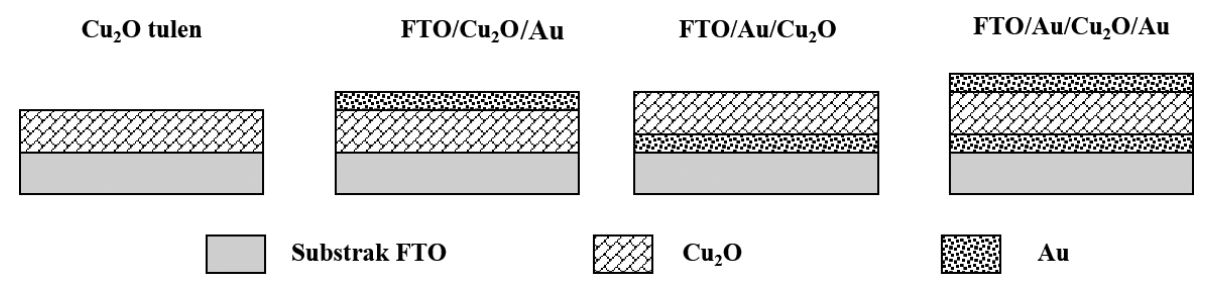

RAJAH 1. Konfigurasi gabungan fotokatod $\mathrm{Cu}_{2} \mathrm{O}$ dan $\mathrm{Au}$ 
dapat dijalankan dengan menggunakan plot Tauc $(-\ln T)^{1 / n}$ melawan (hv). Pintasan pada paksi- $x$ menunjukkan jurang tenaga filem nipis terhasil.

Analisis fotoelektrokimia dilakukan di dalam larutan elektrolit $0.5 \mathrm{M} \mathrm{Na}_{2} \mathrm{SO}_{4}$ di bawah sinaran cahaya xenon $100 \mathrm{~mW} / \mathrm{cm}^{2}$. Elektrod $\mathrm{Ag} / \mathrm{AgCl}$ tepu dan platinum disambung sebagai elektrod rujukan dan elektrod pelengkap. Larutan elektrolit dinyah-gas dengan gas argon selama 30 min sebelum analisis fotoelektrokimia. Kadar imbasan ditentukan pada $0.05 \mathrm{Vs}^{-1}$. Kecekapan fotokatod $\mathrm{Cu}_{2} \mathrm{O}$ dalam tindak balas pembelahan molekul air telah dianggarkan dengan ujian fotoelektrokimia. Ujian ini dijalankan dalam dua keadaan, iaitu keadaan gelap dan keadaan tersinar. Ketumpatan fotoarus yang ditunjukkan dalam Rajah 5 adalah perbezaan ketumpatan arus yang dijana dalam keadaan tersinar dan keadaan gelap (ketumpatan fotoarus = ketumpatan arus keadaan tersinar - ketumpatan arus keaadan gelap).

\section{KEPUTUSAN DAN PERBINCANGAN}

Butiran Au yang diendapkan di atas substrak FTO ditunjukkan dalam Rajah 2. Butiran Au didapati bertaburan secara seragam di atas substrak kaca FTO. Selain itu, saiz butiran Au yang dihasilkan dengan tempoh elektroendapan 1 saat adalah $\sim 20 \mathrm{~nm}$ dan butiran ini didapati cenderung kepada pembentukan gumpalan, seperti yang dilaporkan oleh Wang et al. (2014). Dengan tempoh elektroendapan yang lebih panjang (30 min), butiran Au didapati bertumbuh besar dan bercantum membentuk lapisan yang lebih padat. Selain itu, butiran Au (1 saat) didapati hanya menyerap cahaya pada bahagian 540 hingga $610 \mathrm{~nm}$. Manakala untuk lapisan Au sebagai lapisan bawah (disediakan dengan 30 min), ia mempunyai penyerapan tertinggi pada panjang gelombang $680 \mathrm{~nm}$. Ini bermakna penyerapan cahaya fotokatod $\mathrm{Cu}_{2} \mathrm{O}$ boleh dilanjutkan kepada $820 \mathrm{~nm}$ dengan lapisan Au ini dan lebih cahaya nampak akan diserap untuk penjanaan fotoarus. Ini sejajar dengan yang dilaporkan oleh
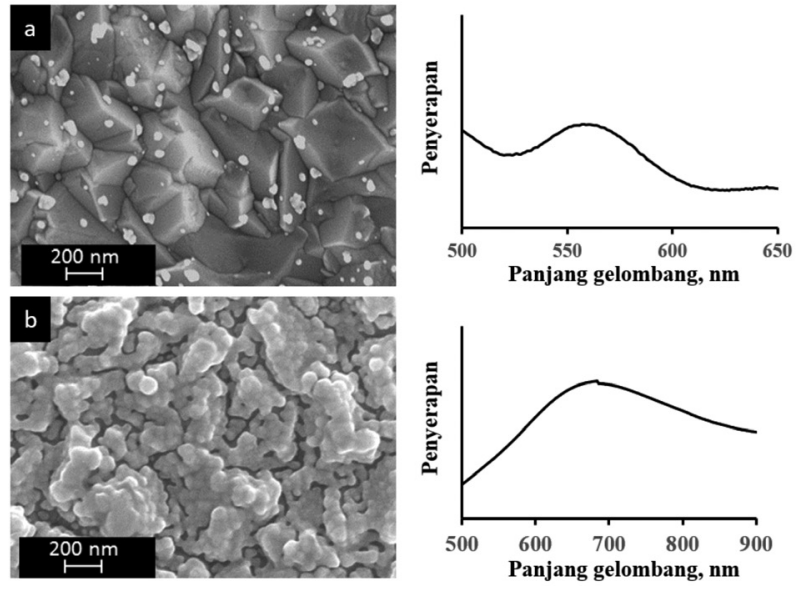

RAJAH 2. Morfologi dan spektrum UV-Vis lapisan Au di atas substrak FTO dengan tempoh elektroendapan yang berbeza, (a) 1 saat dan (b) $30 \mathrm{~min}$
Kawawaki et al. (2013) dengan butiran Au yang padat (30 min, Rajah 2(b)) berbanding Au yang bertabur sekata (1 saat, Rajah 2(a)) akan mengubah penyerapan cahaya ke arah panjang gelombang yang lebih panjang.

Morfologi fotokatod $\mathrm{Cu}_{2} \mathrm{O}$ berbagai konfigurasi telah dipaparkan pada Rajah 3. Didapati bahawa $\mathrm{Cu}_{2} \mathrm{O}$ yang dihasilkan di atas substrak FTO melalui kaedah elektroendapan adalah padat dan tumpat (Rajah 3(a)). Selain itu, butiran Au juga berjaya diendapkan pada permukaan $\mathrm{Cu}_{2} \mathrm{O}$. Butiran kecil ini dapat diperhatikan di dalam Rajah 3(b). Untuk fotokatod $\mathrm{FTO} / \mathrm{Au} / \mathrm{Cu}_{2} \mathrm{O}$, morfologinya didapati sama dengan $\mathrm{Cu}_{2} \mathrm{O}$ tulen. Lapisan $\mathrm{Au}$ di bawah $\mathrm{Cu}_{2} \mathrm{O}$ kelihatan tidak mempengaruhi pertumbuhan lapisan $\mathrm{Cu}_{2} \mathrm{O}$. Manakala untuk fotokatod $\mathrm{Cu}_{2} \mathrm{O}$ terapit $\mathrm{Au}$, butiran $\mathrm{Au}$ juga bertaburan secara seragam di atas lapisan $\mathrm{Cu}_{2} \mathrm{O}$. Kehadiran butiran Au telah ditentukan dengan analisis EDX.

Spektrum UV-Vis fotokatod $\mathrm{Cu}_{2} \mathrm{O}$ telah ditunjukkan dalam Rajah 4. Jurang tenaga $\mathrm{Cu}_{2} \mathrm{O}$ tulen dalam kajian ini adalah $2.2 \mathrm{eV}$ dan ia bersepadanan dengan nilai yang
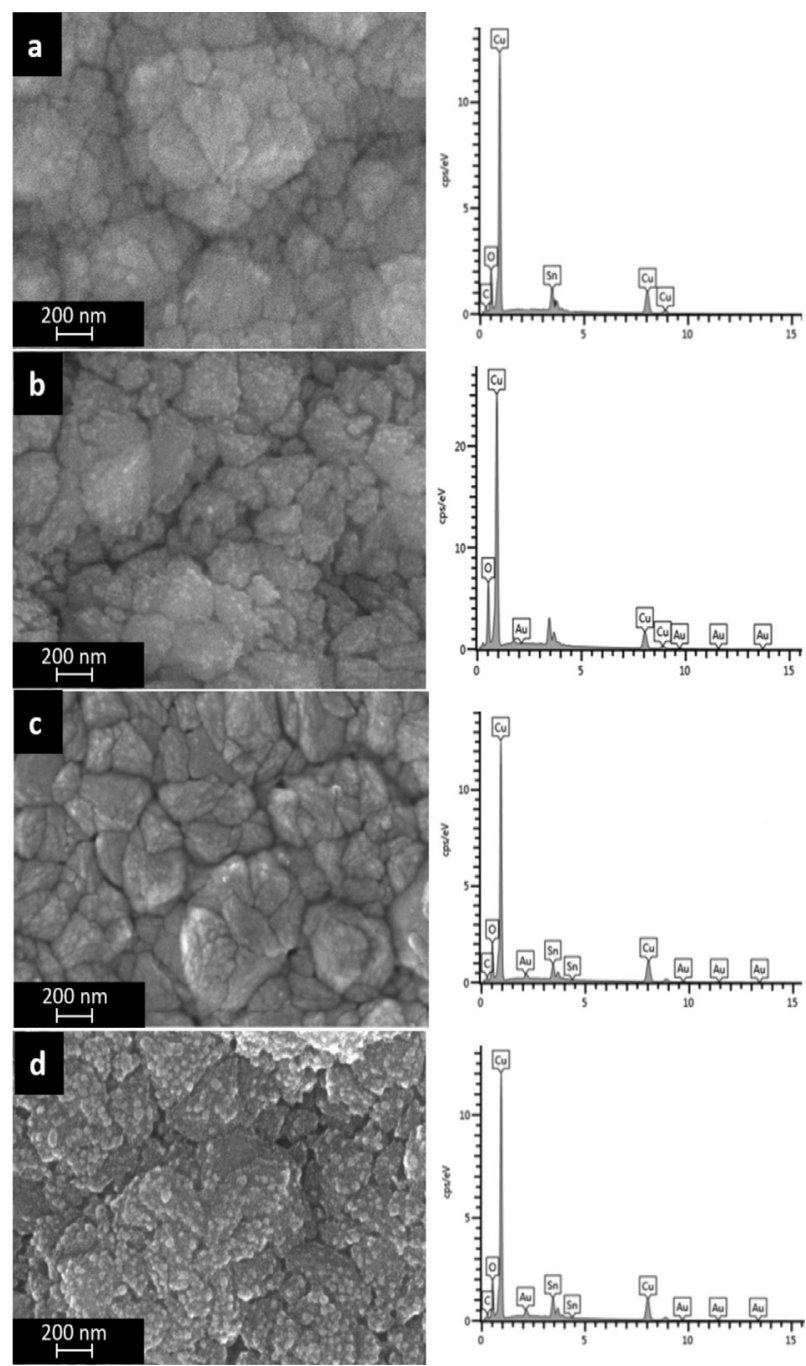

RAJAH 3. Imej FESEM and spektrum EDX (a) $\mathrm{Cu}_{2} \mathrm{O}$ tulen, (b) $\mathrm{FTO} / \mathrm{Cu}_{2} \mathrm{O} / \mathrm{Au}$, (c) FTO $/ \mathrm{Au} / \mathrm{Cu}_{2} \mathrm{O}$ dan (d) $\mathrm{FTO} / \mathrm{Au} / \mathrm{Cu}_{2} \mathrm{O} / \mathrm{Au}$ 
telah dilaporkan (Lee et al. 2017; Liu et al.2016). Apabila butiran $\mathrm{Au}$ (1 saat) dilapiskan di atas $\mathrm{Cu}_{2} \mathrm{O}$, spektrum UV-Vis didapati tidak berubah. Ini kerana jumlah $\mathrm{Au}$ yang diendapkan adalah rendah. Fenomena ini juga dapat diperhatikan semasa perbandingan fotokatod FTO/Au/ $\mathrm{Cu}_{2} \mathrm{O}$ dan $\mathrm{FTO} / \mathrm{Au} / \mathrm{Cu}_{2} \mathrm{O} / \mathrm{Au}$. Ini mencadangkan bahawa butiran $\mathrm{Au}$ (1 saat) pada permukaan fotokatod tidak mempengaruhi nilai jurang tenaga fotokatod.

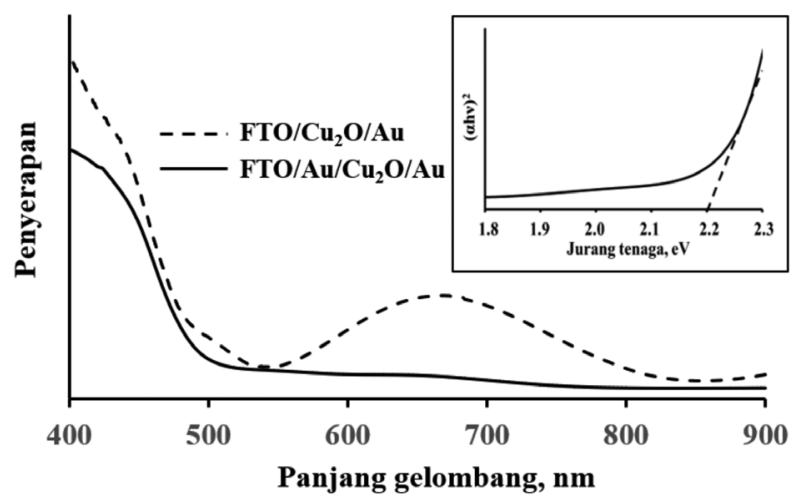

RAJAH 4. Spektrum UV-Vis fotokatod (a) $\mathrm{FTO} / \mathrm{Cu}_{2} \mathrm{O} / \mathrm{Au}$ dan (b) $\mathrm{Cu}_{2} \mathrm{O}$ terapit $\mathrm{Au}$. Inset menunjukkan plot Tauc fotokatod $\mathrm{FTO} / \mathrm{Cu}_{2} \mathrm{O} / \mathrm{Au}$

Dalam ujian ini, didapati bahawa fotoelektrod $\mathrm{Cu}_{2} \mathrm{O}$ telah menghasilkan ketumpatan fotoarus yang negatif dengan voltan pincang negatif. Ini menunjukkan fotoelektrod $\mathrm{Cu}_{2} \mathrm{O}$ yang dihasilkan adalah semikonduktor jenis-p dan bertindak sebagai fotokatod. Apabila butiran $\mathrm{Au}$ diendapkan pada permukaan $\mathrm{Cu}_{2} \mathrm{O}$, fotoarus yang dijana telah meningkat daripada -0.43 kepada $-1.07 \mathrm{~mA} /$ $\mathrm{cm}^{2}$. Peningkatkan penjanaan fotoarus adalah lebih ketara apabila lapisan $\mathrm{Au}$ diendapkan di bawah $\mathrm{Cu}_{2} \mathrm{O}$ (-1.34 $\mathrm{mA} / \mathrm{cm}^{2}$ ). Ini kerana lapisan $\mathrm{Au}$ ini bukan sahaja akan membantu dalam penyerapan cahaya nampak, tetapi juga berperanan sebagai lapisan pengalir cas yang berintangan rendah. Fotoarus tertinggi telah diperhatikan pada fotokatod $\mathrm{Cu}_{2} \mathrm{O}$ terapit $\mathrm{Au}\left(-1.52 \mathrm{~mA} / \mathrm{cm}^{2}\right)$. Konfigurasi ini telah menggabungkan kelebihan Au dalam penyerapan cahaya nampak dan pemindahan cas pada lapisan Au di atas substrat FTO.

Untuk mengenal pasti kehadiran kesan plasmon pada fotokatod, penapis panjang gelombang telah digunakan supaya hanya panjang gelombang yang diingini boleh melepasi penapis semasa ujian fotoelektrokimia. Berdasarkan analisis UV-Vis, panjang gelombang $550 \mathrm{~nm}$ dan $700 \mathrm{~nm}$ telah dipilih untuk menguji kesan plasmon dalam kajian ini. Dalam Rajah 5(b), fotokatod $\mathrm{Cu}_{2} \mathrm{O}$ tulen didapati tidak dapat menjana fotoarus dengan sinaran 700 $\mathrm{nm}$ dan hanya sedikit fotoarus pada $550 \mathrm{~nm}$. Ini kerana tenaga cahaya $700 \mathrm{~nm}$ yang dipancarkan adalah lebih kecil daripada jurang tenaga $\mathrm{Cu}_{2} \mathrm{O}$ dan ia tidak mencukupi untuk menguja $\mathrm{Cu}_{2} \mathrm{O}$ (Rajah 4(a)). Namun begitu, dengan lapisan butiran $\mathrm{Au}$ (1 saat) pada permukaan $\mathrm{Cu}_{2} \mathrm{O}\left(\mathrm{Cu}_{2} \mathrm{O}\right.$ /
$\mathrm{Au})$, fotokatod ini telah menjana fotoarus yang lebih tinggi pada $550 \mathrm{~nm}$. Untuk Au (30 min) di sebelah dalam pula $\left(\mathrm{Au} / \mathrm{Cu}_{2} \mathrm{O}\right)$, pada $500 \mathrm{~nm}$ fotoarus telah bertambah tetapi peningkatan adalah sangat ketara untuk $700 \mathrm{~nm}$ kerana butiran Au yang lebih padat menyebabkan penjerapan pada panjang gelombang yang lebih panajang. Ini telah menunjukkan kehadiran kesan resonans plasmon dan ia telah meningkatkan prestasi fotokatod dalam penjanaan fotoarus.

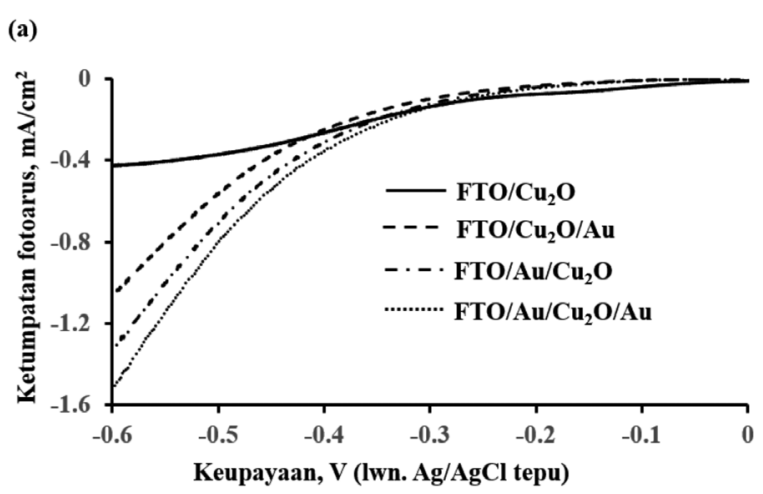

(b)

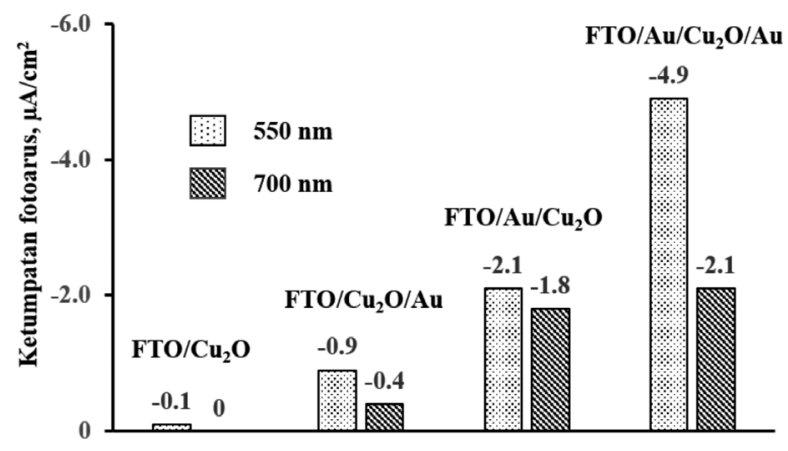

RAJAH 5. Penjanaan fotoarus fotokatod di bawah sinaran cahaya xenon (a) penuh dan (b) pada panjang gelombang tertentu (pada -0.6 lwn. $\mathrm{Ag} / \mathrm{AgCl}$ )

Terdapat tiga mekanisme yang telah dicadangkan untuk menjelaskan peningkatan prestasi fotoelektrokimia, iaitu suntikan elektron panas, pemindahan tenaga resonans plasmon dan serakan cahaya (Pu \& Zhang 2014). Dalam mekanisme suntikan elektron panas, elektron valens logam adi akan tertarik ke antara muka logam/semikonduktor dan dipindah ke jalur pengaliran semikonduktor. Elektron velens yang dipindahkan ini menyebabkan peningkatan yang ketara dalam penjanaan fotoarus di bawah sinaran cahaya nampak. Seperti yang ditunjukkan dalam kajian ini, elektron valens butiran Au yang bebas bergerak akan teruja ke aras $s p$ logam Au apabila cahaya dipancarkan dan kemudiannya disuntik ke jalur pengaliran $\mathrm{Cu}_{2} \mathrm{O}$ (Rajah 6). Elektron ini akan menurunkan molekul air kepada gas hidrogen dan ion hidroksida. Konsep suntikan elektron ini juga terbukti dalam kajian fotopemangkinan $\mathrm{Cu}_{2} \mathrm{O}$ untuk menguraikan bahan sisa organik (Hong et al. 2016; Yuan et al. 2016). 


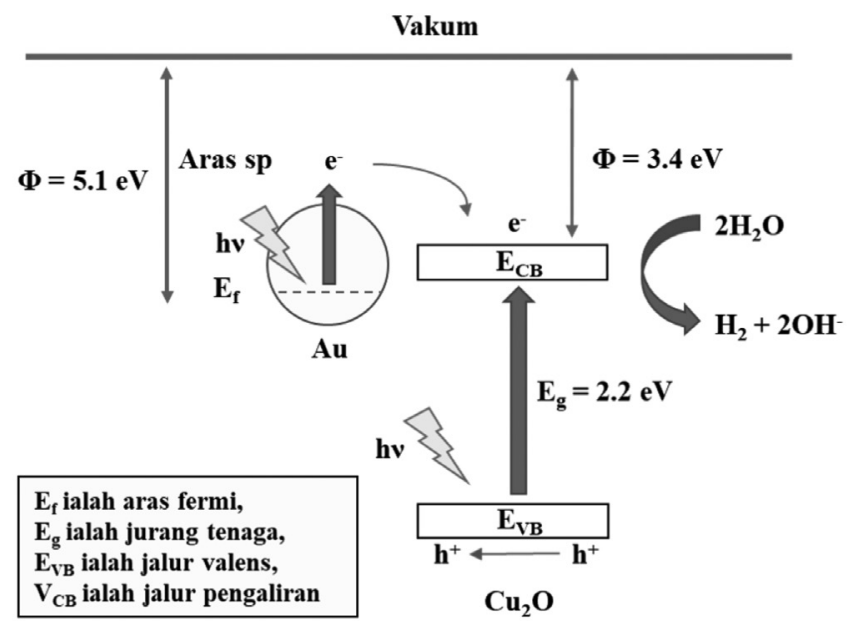

RAJAH 6. Mekanisme suntikan elektron panas di dalam fotokatod

Untuk mekanisme pemindahan tenaga resonans plasmon, elektron valens butiran logam yang berayun dengan medan elektromagnet (cahaya nampak) akan menghasilkan interaksi dwikutub dan menguatkan medan elektrik pada permukaan semikonduktor. Ini akan mengaruh penjanaan pasangan elektron-lohong pada permukaan semikonduktor. Oleh itu, lebih banyak pasangan elektron-lohong terhasil dan mempertingkatkan fotoaktiviti. Mekanisme pemindahan tenaga resonans plasmon ini juga boleh berlaku pada fotokatod $\mathrm{Cu}_{2} \mathrm{O}$ berplasmon (Duchene et al. 2016) tetapi ia memerlukan kajian lebih terperinci untuk pembuktian. Untuk mekanisme serakan cahaya, butiran logam pada permukaan semikonduktor akan mengelakkan pantulan sinaran cahaya pada permukaan semikonduktor yang licin. Pantulan sinaran cahaya ini akan dibelau dan meresap ke lapisan semikonduktor. Ini akan meningkatkan kegunaan sinaran cahaya untuk tindak balas fotoelektrokimia. Walau pun demikian, mekanisme ini didapati hanya berlaku sekiranya saiz butiran logam adi pada permukaan semikonduktor melebihi $50 \mathrm{~nm}$ (Zhang et al.2015). Oleh kerana butiran $\mathrm{Au}$ pada permukaan fotokatod $\mathrm{Cu}_{2} \mathrm{O}$ dalam kajian adalah lebih kecil daripada $50 \mathrm{~nm}$, mekanisme ini dijangka tidak boleh berlaku.

\section{KESIMPULAN}

Dalam kajian ini, fotokatod $\mathrm{Cu}_{2} \mathrm{O}$ berplasmon telah berjaya dihasilkan dalam konfigurasi yang berbeza. Kehadiran butiran Au telah dibuktikan dengan FESEM dan EDX. Penyerapan plasmon oleh partikel Au yang diendap pada fotokatod telah meningkatkan penyerapan cahaya nampak $\mathrm{Cu}_{2} \mathrm{O}$, justeru meningkatkan keberkesanan fotokatod $\mathrm{Cu}_{2} \mathrm{O}$ dalam tindak balas fotoelektrokimia. Selain itu, fotokatod $\mathrm{Cu}_{2} \mathrm{O}$ terapit $\mathrm{Au}$ didapati telah menghasilkan fotoarus yang tertinggi dalam kajian ini. Mekanisme pemindahan cas telah diterangkan dengan konsep suntikan elektron panas.

\section{PENGHARGAAN}

Pengarang mengucapkan terima kasih kepada Universiti Kebangsaan Malaysia yang menaja penyelidikan ini melalui peruntukan FRGS/1/2014/SG01/UKM/02/1 dan GUP-2013-068.

\section{RUJUKAN}

Baxter, J.B., Richter, C. \& Schmuttenmaer, C.A. 2014. Ultrafast carrier dynamics in nanostructures for solar fuels. Annu. Rev. Phys. Chem 65(1): 423-447.

Choudhary, S., Upadhyay, S., Kumar, P., Singh, N., Satsangi, V.R., Shrivastav, R. \& Dass, S. 2012. Nanostructured bilayered thin films in photoelectrochemical water splitting - A review. International Journal of Hydrogen Energy 37(24): 1871318730.

Duchene, J.S., Williams, B.P., Johnston-Peck, A.C., Qiu, J., Gomes, M., Amilhau, M., Bejleri, D., Weng, J., Su, D., Huo, F., Stach, E.A. \& Wei, W.D. 2016. Elucidating the sole contribution from electromagnetic near-fields in plasmonenhanced $\mathrm{Cu}_{2} \mathrm{O}$ photocathodes. Advanced Energy Materials 6(1): $1-10$.

Gao, H., Zhang, P., Hu, J., Pan, J., Fan, J. \& Shao, G. 2017. One-dimensional Z-scheme $\mathrm{TiO}_{2} / \mathrm{WO}_{3} / \mathrm{Pt}$ heterostructures for enhanced hydrogen generation. Applied Surface Science 391(Part B): 211-217.

Grätzel, M. 2017. The rise of highly efficient and stable perovskite solar cells. Accounts of Chemical Research 50(3): 487-491.

Hong, J.W., Wi, D.H., Lee, S.U. \& Han, S.W. 2016. Metalsemiconductor heteronanocrystals with desired configurations for plasmonic photocatalysis. Journal of the American Chemical Society 138(48): 15766-15773.

Hu, M., Chen, J., Li, Z.Y., Au, L., Hartland, G.V., Li, X., Marquez, M. \& Xia, Y. 2006. Gold nanostructures: Engineering their plasmonic properties for biomedical applications. Chemical Society Reviews 35(11): 1084-1094.

Hutchins, M.G., Abu-Alkhair, O., El-Nahass, M.M. \& Abd ElHady, K. 2006. Structural and optical characterisation of thermally evaporated tungsten trioxide $\left(\mathrm{WO}_{3}\right)$ thin films. Materials Chemistry and Physics 98(2-3): 401-405.

Jaafar, N.S.H., Minggu, L.J., Arifin, K. \& Kassim, M.B. 2017. Natural dyes as $\mathrm{TiO}_{2}$ sensitizers with membranes 
for photoelectrochemical water splitting: An overview. Renewable and Sustainable Energy Reviews 78: 698-709.

Kalamaras, E., Dracopoulos, V., Sygellou, L. \& Lianos, P. 2016. Electrodeposited Ti-doped hematite photoanodes and their employment for photoelectrocatalytic hydrogen production in the presence of ethanol. Chemical Engineering Journal 295: 288-294.

Kawawaki, T., Takahashi, Y. \& Tatsuma, T. 2013. Enhancement of dye-sensitized photocurrents by gold nanoparticles: Effects of plasmon coupling. J.Phys. Chem.C. 117(11): 5901-5907.

Lee, Y.G., Wang, J.R., Chuang, M.J., Chen, D.W. \& Hou, K.H. 2017. The effect of electrolyte temperature on the electrodeposition of cuprous oxide films. International Journal of Electrochemical Science 12: 507-516.

Leong, K.H., Liu, S.L., Sim, L.C., Saravanan, P., Jang, M. \& Ibrahim, S. 2015. Surface reconstruction of titania with g- $\mathrm{C}_{3} \mathrm{~N}_{4}$ and $\mathrm{Ag}$ for promoting efficient electrons migration and enhanced visible light photocatalysis. Applied Surface Science 358(Part A): 370-376.

Lewis, N. 2016. Research opportunities to advance solar energy utilization. Science 351(6271): aad1920.

Li, J., Cushing, S.K., Bright, J., Meng, F., Senty, T.R., Zheng, P., Bristow, A.D. \& Wu, N. 2013. Ag@ $\mathrm{Cu}_{2} \mathrm{O}$ core-shell nanoparticles as visible-light plasmonic photocatalysts. ACS Catalysis 3(1): 47-51.

Liu, L., Ding, L., Liu, Y., An, W., Lin, S., Liang, Y. \& Cui, W. 2016. Enhanced visible light photocatalytic activity by $\mathrm{Cu}_{2} \mathrm{O}$ coupled flower-like $\mathrm{Bi}_{2} \mathrm{WO}_{6}$ structures. Applied Surface Science 364: 505-515.

Mark-Lee, W.F., Ng, K.H., Minggu, L.J., Umar, A.A. \& Kassim, M.B.2012. Determination of band energy levels for tungsten nitrosyldithiolene. Sains Malaysiana 41(4): 439-444.

Mi, Y., Wen, L., Xu, R., Wang, Z., Cao, D., Fang, Y. \& Lei, Y. 2016. Constructing a $\mathrm{AZO} / \mathrm{TiO}_{2}$ core/shell nanocone array with uniformly dispersed Au NPs for enhancing photoelectrochemical water splitting. Advanced Energy Materials 6(1): 1-8.

Ng, K.H., Minggu, L.J., Jaafar, N.A. \& Kassim, M.B. 2017. Enhanced plasmonic photoelectrochemical response of $\mathrm{Au}$ sandwiched $\mathrm{WO}_{3}$ photoanodes. Solar Energy Materials \& Solar Cells 172: 361-367.

Ng, K.H., Minggu, L.J., Jumali, M.H.H. \& Kassim, M.B. 2012. Fotoelektrod tungsten trioksida terdop nikel untuk tindak balas pembelahan air fotoelektrokimia. Sains Malaysiana 41(7): 893-899.

Ng, K.H., Minggu, L.J., Mark-Lee, W.F., Arifin, K., Jumali, M.H.H. \& Kassim, M.B. 2018. A new method for the fabrication of a bilayer $\mathrm{WO}_{3} / \mathrm{Fe}_{2} \mathrm{O}_{3}$ photoelectrode for enhanced photoelectrochemical performance. Materials Research Bulletin 98: 47-52.

Pazos-Outón, L.M., Lee, J.M., Futscher, M.H., Kirch, A., Tabachnyk, M., Friend, R.H. \& Ehrler, B. 2017. A siliconsinglet fission tandem solar cell exceeding $100 \%$ external quantum efficiency with high spectral stability. ACS Energy Letters 2(2): 476-480.

Pu, Y. \& Zhang, J.Z. 2014. Mechanisms behind plasmonic enhancement of photocurrent in metal oxides. Austin Journal of Nanomedicine and Nanotechnology 2(5): 1-4.

Redecka, M., Rekas, M., Trenczek-Zajac, A. \& Zakrzewska, K. 2008. Importance of the band gap energy and flat band potential for application of modified $\mathrm{TiO}_{2}$ photoanodes in water photolysis. Journal of Power Sources 181(1): 46-55.
Sim, L.C., Leong, K.H., Ibrahim, S. \& Saravanan, P. 2014. Graphene oxide and Ag engulfed $\mathrm{TiO}_{2}$ nanotube arrays for enhanced electron mobility and visible-light-driven photocatalytic performance. Journal of Materials Chemistry A 2(15): 5315-5322.

Tang, Q. 2017. All-weather solar cells - A rising photovoltaic revolutionary. Chemistry - A European Journal 23(34): 8118-8127.

Verma, A., Srivastav, A., Banerjee, A., Sharma, D., Sharma, S., Singh, U.B., Satsangi, V.R., Shrivastav, R., Avasthi, D.K. \& Dass, S. 2013. Plasmonic layer enhanced photoelectrochemical response of $\mathrm{Fe}_{2} \mathrm{O}_{3}$ photoanodes. Journal of Power Sources 315: 152-160.

Wang, B., Li, R., Zhang, Z., Zhang, W., Yan, X., Wu, X., Cheng, G. \& Zheng, R. 2017. Novel Au/ $\mathrm{Cu}_{2} \mathrm{O}$ multishelled porous heterostructures for enhanced efficiency of photoelectrochemical water splitting. Journal of Materials Chemistry A 5(27): 14415-14421.

Wang, T., Jin, B., Jiao, Z., Lu, G., Ye, J. \& Bi, Y. 2014. Photodirected growth of Au nanowires on $\mathrm{ZnO}$ arrays for enhancing photoelectrochemical performances. Journal of Materials Chemistry A 2(37): 15553-15559.

Yang, J.,Li,Z.,Zhao, C., Wang, Y. \& Liu, X. 2014. Facile synthesis of $\mathrm{Ag}-\mathrm{Cu}_{2} \mathrm{O}$ composites with enhanced photocatalytic activity. Materials Research Bulletin 60: 530-536.

Ye, W., Long, R., Huang, H. \& Xiong, Y. 2016. Plasmonic nanostructures in solar energy conversion. J. Mater. Chem. C 5: 1008-1021.

Yuan, G.Z., Hsia, C.F., Lin, Z.W., Chiang, C., Chiang, Y.W. \& Huang, M.H. 2016. Highly facet-dependent photocatalytic properties of $\mathrm{Cu}_{2} \mathrm{O}$ crystals established through the formation of $\mathrm{Au}$-decorated $\mathrm{Cu}_{2} \mathrm{O}$ heterostructures. Chemistry - A European Journal 22(35): 12548-12556.

Zhang, L., Herrmann, L.O. \& Baumberg, J.J. 2015. Size dependent plasmonic effect on $\mathrm{BiVO}_{4}$ photoanodes for solar water splitting. Scientific Reports 5: 16660.

Kim Hang Ng, Lorna Jeffery Minggu* \& Nurul Akmal Jaafar Institut Sel Fuel

Universiti Kebangsaan Malaysia

43600 UKM Bangi, Selangor Darul Ehsan

Malaysia

Mohammad B. Kassim

Pusat Pengajian Sains Kimia dan Teknologi Makanan

Fakulti Sains dan Teknologi

Universiti Kebangsaan Malaysia

43600 UKM Bangi, Selangor Darul Ehsan

Malaysia

*Pengarang untuk surat-menyurat: email: lorna_jm@ukm.edu.my

Diserahkan: 30 Jun 2017

Diterima: 19 Februari 2018 